\title{
KERTAS SEBAGAI BAHAN PEMBUATAN KOSTUM PERTUNJUKAN NASKAH THE PIRAMUS AND TISBI KARYA SHAKESPEARE TERJEMAHAN SUYATNA ANIRUN
}

\author{
Hidayah Kartikasari \\ Institut Seni Indonesia Yogyakarta
}

\begin{abstract}
Abstrak: Piramus dan Tisbi adalah kisah cinta tragis yang populer pada $331 \mathrm{SM}$ di Babilonia. Pada 1590-an William Shakespeare menulis drama berjudul Mid Summer Night's Dream di akhir cerita, yang memasukkan kisah-kisah Piramus dan Tisbi. Tahun 1960-an kemudian diadaptasi oleh Suyatna Anirun sebagai drama pendek Piramus dan Tisbi dalam bentuk komedi. Pencipta kostum menggunakan naskah tersebut untuk mewujudkan penciptaan kostum teater. Pencipta kostum perlu memahami karakter sehingga tercapai hubungan harmonis antara karakter dengan kostum yang dikenakannya. Teori estetika digunakan untuk menghadirkan estetika dalam penciptaan kostum kertas yang akan digunakan dalam pertunjukan. Hasil proses penciptaan karya busana dalam naskah Piramus dan Tisbi dengan material kertas ini mengalami banyak kendala dan beberapa kali perubahan, hingga mencapai bentuk yang menyesuaikan kebutuhan pementasan.
\end{abstract}

Kata kunci: Piramus and Tisbi, kostum teater, estetika, kostum kertas

\begin{abstract}
Piramus and Tisbi is a tragic love story popular in 331 BC Babylon. In the 1590s William Shakespeare wrote a drama called Mid Summer Night's Dream that by the end of the story, it included the story of Piramus and Tisbi. The story was later adapted by Suyatna Anirun as a short drama of Piramus and Tisbi in the form of comedy in 1960s. The costume creator uses the script to realize the creation of the theater costume. The costume creator needs to understand the character to create a fitting costume for the characters. Aesthetic theory is used to present aesthetics in the creation of paper costumes that will be used in performances. The result of the costume creation process in the Piramus and Tisbi play with paper materials, has experienced many obstacles and has been revised for several times, to reach a form that matches the stage needs.
\end{abstract}

Key words: Piramus and Tisbi, theater costume, aesthetics, paper costume

\section{Pendahuluan}

Kertas sebagai bahan penciptaan tata busana dalam suatu pertunjukan teater, merupakan hal yang tidak mudah diciptakan, perlu memahami karakter, kelemahan dan kelebihan kertas. Bahan kertas sebagai gambaran busana berdasarkan perwatakan pemain pada suatu naskah. Antara pakaian dan perwatakan yang dibawakan pelakunya harus serasi, tidak mengada-ada agar penilaian penonton tidak pada pakaian saja, melainkan garapan dramanya seimbang secara keseluruhan. Busana merupakan bagian tata artistik terpenting dalam mendukung jalannya suatu pertunjukan selain tata rias, tata panggung dan tata cahaya.

Kita ketahui bahwa kata "busana" memberi pengertian bahwa yang dimaksudkan adalah pakaian khusus yang ada kaitannya dengan kesenian. Sehingga pakaian khusus dalam kehidupan kitapun dapat dikatakan "busana", apabila dikaitkan dengan peristiwa atau kegiatan yang ada 
hubungannya dengan keindahan dan setidaktidaknya berhubungan dengan seni. Di dalam Kamus Bahasa Kawi Indonesia bahwa "bhusana" adalah berarti pakaian, sedangkan dalam "Pangaweroeh" Basa Kawi" Volksalmanak Soenda "bhusana" berarti hiasan badan. Oleh sebab itu dapat disimpulkan bahwa yang dimaksud dengan busana segala perlengkapan yang menyertai untuk menggambarkan tokoh. Termasuk segala aksesorisnya dan segala unsur yang melekat pada busana yang dikenakan tokoh (Nuraini, 2011).

Busana adalah bahan tekstil atau bahan lainnya yang sudah dijahit atau tidak dijahit yang dipakai atau disampirkan untuk penutup tubuh seseorang (Riyanto, 2003). Buat pola dan bentuk pakaian (busana) menurut kebutuhan yang dituntut naskah, memang ada pola maupun bahan pakaian yang memerlukan biaya besar dan rumit, namun demikian bukan berarti menggagalkan rencana pementasan, sutradara dan juru busana harus mencari jalan lain agar pola dan biaya pembuatan pakaian yang demikian itu dapat diwujudkan, kalau tidak bisa persis buat kemiripan tapi bukan penyimpangan (M. Djoddy, 1992).

Permasalahan yang dikemukakan kiranya memberi rangsangan tertentu berupa ekplorasi bahan dengan bahan kertas. Kertas adalah barang yang sangat dibutuhkan oleh kebanyakan orang di zaman modern ini sebagai alat baca tulis, pembungkus, bahan seni dalam bereksplorasi dan masih banyak lagi. Memang kebutuhan akan kertas tidak lagi menjadi masalah. Kertas ada dimana saja dengan berbagai macam jenis, ukuran, warna dan harga (Harianto, 2002).

Kelemahan kertas antara lain mudah robek, tidak kedap air dan mudah kusut. Sedangkan kelebihan kertas adalah ringan, ramah lingkungan, mudah diolah dan harganya pun terjangkau. Pada penciptaan busana akan menggunakan kertas sebagai bahan utama dan kain sebagai bahan pelapis. Bahan kertas yang akan digunakan antara lain: kertas mecy, kertas tyvek, board paper, kertas loose liner, kertas coated, kertas concorde, foam net. Dalam penciptaan busana dengan bahan kertas tidak berdiri sendiri, pencipta menggunakan bahan lain berupa kain tile, kain sintex dan taroko sebagai bahan dasar. Kertas biasanya dipakai atau dikenakan dalam acara fashion show. Pada umumnya kertas dianggap tidak bernilai, namun sebaliknya kertas dapat disulap menjadi busana yang bernilai seni. Selama ini tak banyak masyarakat yang memahami cara memanfaatkan kertas dengan baik. Bahan kertas, sebagai media dalam pemanfaatan bahan yang ada, selain itu sebagai strategi untuk mendorong proses imajinatif dan berpikir kreatif.

Lia Griffith seorang desainer papercrafter yang membuat baju kertas pertama sekitar sepuluh tahun lalu, dan sejak saat itu ia telah membuat hampir 40 gaun secara total. Gaunnya ditampilkan pada acara-acara amal, di empat pertunjukan runway, sebuah iklan di China. Dengan bahan yang belum pernah dipakai untuk gaun kertas sebelumnya. Sepertinya krep akan menjadi bahan kertas yang jelas untuk membuat gaun, dulu ia selalu menggunakan majalah daur ulang atau kertas fotocopy. Ia menggunakan kertas krep untuk membuat gaun pada acara Pameran Alat Tulis National 2016. Berdasarkan pengalaman tersebut menginspirasi penata busana dalam menciptakan busana dengan bahan kertas.

Maka dari itu melalui penciptaan busana dengan bahan kertas dalam pementasan tugas akhir naskah Piramus dan Tisbi karya William Shakespeare terjemahan Suyatna Anirun menjadikan pakaian yang ready to use pada sebuah pertunjukan teater. Busana ini diciptakan bukan sebagai pakaian sehari-hari, melainkan busana khusus yang dirancang dalam pertunjukan teater, pada tiap pertunjukan mempunyai ruang gerak 
tidak terbatas atau lebih luas. Sedangkan pada acara fashion show, beda tata ruang yang dipakai untuk catwalk. Ini menjadi tantangan bagi penata busana sendiri bagaimana menciptakan busana dengan bahan kertas agar lebih nyaman untuk bergerak.

Piramus dan Tisbi adalah kisah cinta yang populer di Babilonia pada tahun 331 SM. Merupakan kisah cinta tragis yang terpisahkan oleh maut. Pada tahun 1590-an William Shakespeare menulis sandiwara komedi berjudul a Mid Summer Night's Dream di akhir cerita ia menyisipkan kisah Piramus dan Tisbi. Pada tahun 1960-an disadur oleh Suyatna Anirun sebagai drama pendek naskah Piramus dan Tisbi karya William Shakespeare dan dikemas dalam bentuk komedi, berbeda dengan kisah asli yang menceritakan tragedi. Di dalam naskah tersebut menghadirkan lima tokoh diantaranya: Piramus, Tisbi, Cahaya Bulan, Singa dan Tembok. Pemilihan naskah Piramus dan Tisbi karya William Shakespeare terjemahan Suyatna Anirun dalam penciptaan tata busana karena ketertarikan pencipta busana pada cerita tersebut dan tokoh-tokoh yang ada memberikan tantangan bagi pencipta busana dalam mengeksplorasi bahan berupa kertas. Berkaitan dengan topik, kertas memberi kesan estetik busana yang akan dipakai pada naskah drama non-realis berbeda dengan naskah drama realis. Pementasan drama realis pada umumnya busana yang dipakai ialah busana dalam kehidupan keseharian masyarakat.

Busana pada pertunjukan Piramus dan Tisbi karya William Shakespeare terjemahan Suyatna Anirun akan mengekplorasi kertas pada tiap tokohnya. Bahan-bahan pakaian yang dikenakan tokoh Piramus, Tisbi, Cahaya Bulan, Singa dan Tembok merupakan : kertas mecy, kertas tyvek, board paper, kertas loose liner, kertas coated, kertas concorde, foam net. Mengusung
Tema kertas sebagai bahan pokok dalam pembuatan busana pertunjukan drama.

Tujuan Penciptaan

Tujuan merupakan tahap yang ingin diperoleh dari suatu proses pemecahan masalah. Dari rumusan penciptaan di atas, maka tujuan dari proses penciptaan sebagai berikut :

1. Untuk menciptakan busana dengan bahan kertas berdasarkan karakter tokohtokoh dalam lakon Piramus dan Tisbi.

2. Untuk memperluas pengetahuan kertas sebagai busana dalam pementasan teater.

\section{Tinjauan Pustaka}

Sebuah teori berfungsi untuk membuat ukuran-ukuran atau kriteria untuk dijadikan dasar dalam pembuktian sesuatu (Prasetya, 2013). Sebelum mencipta suatu karya busana dalam sebuah pertunjukan perlu kiranya kita memahami kertas apa yang digunakan, kemudian memahami karakter kertas berdasarkan kelebihan dan kelemahan sebagai bahan, kemudian memanfaatkan bahan tersebut dan mewujudkan dalam penciptaan busana Piramus dan Tisbi.

Kemampuan menggunakan teori bukanlah proses yang instan, tetapi terwujud dari suatu proses belajar yang cukup lama. Dalam proses ini si peneliti tidak hanya belajar untuk mengetahui konsep-konsep dan mengingatnya dengan cara menghafalkannya, tetapi harus memahami konsep-konsep tersebut dengan cara menggunakannya untuk memahami kenyataan-kenyataan yang dihadapinya dan mengkaitkannya dengan menggunakan konsep-konsep tersebut (Prasetya, 2013).

Pakaian dapat berfungsi sebagai alat identifikasi diri, sedangkan pakaian dalam kehidupan sosial berfungsi menandakan peran sosial masing-masing pemakainya (Sahid, 2004). Tidaklah terlalu berlebihan apabila busana yang kita kenakan 
merupakan sarana untuk menyampaikan misi atau pesan kepada orang lain, atau dengan kata lain busana digunakan sebagai sarana komunikasi non verbal. Seperti halnya pendapat Hariani Mardjono (1991) yang mengatakan bahwa "Busana memperlihatkan siapa dia itu", maksudnya dengan busana-busana ini merupakan tolok ukur bagi martabat, kedudukan dari seseorang dalam masyarakat.

Estetika sebagai suatu filsafat, hakikatnya telah menempatkannya pada keindahan dan makna. Estetika seperti terdapatnya tumpang-tindih pengertian antara seni (art), karya seni (work of arts), filsafat seni (philosophy of art), nilai estetik (aesthetic value), estetis estetik (aesthetic) dan estetik (aesthetics). Istilah tersebut sering digunakan untuk pengertian sama, padahal semuanya memiliki perbedaan yang penting. Beberapa pengertian estetika dan lingkupnya dicermati di bawah ini:

1. Estetika adalah segala sesuatu dan kajian terhadap hal-hal yang berkaitan dengan kegiatan seni (Kattsoff, 1953).

2. Estetika merupakan kajian filsafat keindahan dan keburukan (Stolnitz dalam Edwards, 1967).

3. Estetika adalah suatu ilmu yang mempelajari segala sesuatu yang berkaitan dengan keindahan, mempelajari semua aspek yang disebut keindahan (AA. Djelantik, 1999).

4. Estetika adalah filsafat yang membahas esensi dari totalitas kehidupan estetik dan artistic yang sejalan dengan zaman (Sachari, 2002).

Pemikiran tentang indah biasanya akan nampak pada keindahan yang tersentuh secara indrawi atau disebut sebagai symmetria. Dalam pengertian yang terbatas, keindahan hanya tertuju pada benda yang terserap melalui penglihatan, yaitu berupa bentuk dan warna. Pandangan lainnya, keindahan diartikan sebagai estetika murni yang berusaha mengungkapkan pengalaman estetis dari seseorang dalam keterkaitannya dengan segala sesuatu yang diserapnya (Kartika \& Perwira, 2004).

Kertas merupakan barang yang sering digunakan oleh banyak orang dalam seharihari. Kertas cenderung mudah dibentuk dengan berbagai sudut dan motif. Kertas mempunyai karakteristik berupa warna, jenis dan tekstur. Pencipta busana mempunyai konsep busana dalam menghadirkan estetika dari kertas. Estetika pada kertas akan dihadirkan dalam penciptaan busana berdasarkan karakter tokoh-tokoh dalam lakon Piramus dan Tisbi karena, kertas mempunyai karakteristik sendiri baik berupa warna, jenis dan tekstur.

Estetika yang dihadirkan tidak terpaku pada bentuk, diutamakan lebih eksploratif. Seiring perkembangan zaman dunia mode mulai berubah. Pencipta busana mempunyai konsep tersendiri dalam proses penciptaan busana yang tidak terpaku pada naskah di zaman tersebut. Lebih memilih busana yang dapat diterima oleh masyarakat dan lingkungan sekitar, sebaiknya tidak menyimpang jauh dari nilai-nilai kepribadian yang tercermin melalui estetika dan etika penampilan suatu tata krama dalam masyarakat.

Hal ini mengingat bahwa sekarang berada dalam lingkungan masyarakat yang beragam dan keadaan yang penuh dengan perubahan-perubahan yang cepat sekali geraknya. Perubahan dalam dunia mode itu sendiri disebabkan adanya dinamika yang tumbuh dan berkembang dalam masyarakat, dengan pengaruh dinamika ini kita terdorong untuk mengikutinya. Penampilan yang menarik bukanlah monopoli wanita cantik, dan setiap wanita mempunyai sisi yang menarik, tergantung pada wanita itu sendiri dalam pengembangan dirinya yang sebaik-baiknya, seutuhnya. Pernyataan ini juga disepakati oleh Ghea Panggabean yang mengatakan "up to date itu harus, dan 
merupakan sebuah tuntutan dalam mode agar selalu trendi" (Daradjatun \& Watimena, 2003).

Berbicara mode (fashion) berkaitan dengan selera individu, masyarakat yang akan dipegaruhi oleh lingkungan budaya tertentu, khususnya selera dalam mode busana. Kebutuhan akan busana pada individu atau sekelompok orang akan ditentukan oleh aktivitas yang dilakukan, perhatian akan berbusana, kondisi ekonomi dan semakin kuatnya perkembangan mode busana, serta perkembangan teknologi (Riyanto, 2009).

Dengan perkembangan teknologi salah satunya akan mempunyai dampak pada hasil teknologi tekstil yang berkaitan dengan perkembangan busana. Dari teknologi tekstil yang sudah cukup berkembang menghasilkan berbagai produk bahan busana beragam dalam jenis dan sifat kain, warna, corak, atau motif kain. Produk teknologi tekstil akan mendorong munculnya berbagai model busana yang dibutuhkan oleh individu atau kelompok masyarakat tertentu dalam lingkungan tertentu.

\section{Metode Penciptaan}

Metode adalah cara yang digunakan dalam melakukan sesuatu untuk mencapai hasil sesuai apa yang diharapkan. Mewujudkan konsep penciptaan tata busana menggunakan material kertas untuk kepentingan pentas drama merupakan tujuan dari penciptaan busana ini. Metode penciptaan yang digunakan mengacu pada apa yang ada di lingkungan sekitar maupun peristiwa-peristiwa penting yang dianggap menarik untuk dikembangkan dan dituangkan dalam penciptaan suatu karya tata busana.

Pencipta busana mencoba memahami dan mengaplikasikan kertas dengan memberi rangsangan tertentu misalnya berupa ekplorasi bahan. Proses pembuatan busana bermula pada pengumpulan kemudian pengelompokan kertas berdasarkan jenisnya dan mengeksplorasi bahan tersebut menjadi busana tokoh dalam naskah Piramus dan Tisbi karya William Shakespeare terjemahan Suyatna Anirun diantaranya Piramus, Tisbi, Cahaya Bulan, Singa dan Tembok.

Untuk mempermudah proses penciptaan busana, perlu diberikan stimulan berupa tahapan untuk mencapai hasil sesuai apa yang diharapkan. Tahapan penciptaan busana tokoh dalam naskah Piramus dan Tisbi karya William Shakespeare terjemahan Suyatna Anirun dapat dilihat pada lampiran Gambar. 1.

Analisis Cerita Naskah Piramus dan Tisbi Analisis cerita naskah Piramus dan Tisbi menggunakan teknik analisis struktural intrinsik dengan mengidentifikasi cerita melalui cara membaca, menafsirkan isi cerita yang diambil dari naskah, mengulas lebih dalam serta mendeskripsikan.

\section{Analisis Karakter Tokoh Naskah Piramus dan Tisbi}

Analisis karakter merupakan langkah kedua yang digunakan dalam proses penciptaan busana untuk mengidentifikasi karakter tokoh naskah Piramus dan Tisbi. Menurut Oemarjati unsur karakter (character) yang dalam drama biasa disebut tokoh, adalah bahan yang paling aktif untuk menggerakkan alur. Lewat penokohan ini, pengarang dapat mengungkapkan alasan logis terhadap tingkah laku tokoh. Tokohtokoh inilah yang akan membawakan tema dalam keseluruhan rangkaian latar dan alur (Dewojati, 2012). Analisis adalah upaya untuk memahami yang bertujuan dalam menyimpulkan suatu pendapat, agar sebuah pertunjukan dapat dimengerti oleh penonton.

Membuat Konsep Busana 
Menentukan konsep busana merupakan langkah ketiga. Pada penciptaan busana dalam naskah Piramus dan Tisbi akan direalisasikan dengan bahan menggunakan bahan kertas. Konsep penciptaan busana akan menggunakan bahan kertas, antara lain: kertas mecy, kertas tyvek, board paper, kertas loose liner, kertas coated, foam net. Dalam penciptaan ini busana dengan bahan kertas tidak berdiri sendiri, penulis menggunakan bahan lain berupa kain sintex, taroko dan tyle sebagai bahan lapisan.

Membuat Rancangan Busana

Membuat rancangan busana

merupakan langkah keempat dalam proses penciptaan busana tokoh dalam naskah Piramus dan Tisbi. Desain busana pada hakikatnya erat hubungannya dengan masalah mode, karena desain busana pada dasarnya adalah mencipta mode atau mencipta model pakaian (Kamil, 1986). Desain model yaitu desain yang dibuat sesuai dengan bentuk tubuh, usia, waktu dan kesempatan pemakaian. Desain bisanya berupa sketsa. Sketsa tubuh digambar sesuai kebutuhan dalam rancangan busana. Model busana digambar sesuai dengan konsep garapan. Aksesori dan perlengkapan dikreasikan dengan pertimbangan keselarasan rancangan busana.

Mode itu sendiri cabang dari seni rupa. Karya seni rupa mempunyai suatu desain yaitu suatu rupa yang dihasilkan karena susunan unsur-unsurnya. Unsurunsur dalam suatu desain adalah susunan garis, bentuk, warna dan tekstur (Chodiyah \& Mamdi, 1982). Jenis dan karakter kain, motif dan corak dipilih sesuai dengan rancangan busana. Warna busana ditentukan sesuai dengan konsep garapan.

Perancangan dan penggarapan busana akan lebih mudah jika dituangkan dalam bentuk sketsa agar dapat disesuaikan ke dalam bentuk visual panggung. Menurut Graves (1951), unsur-unsur dalam desain dapat direduksi ke dalam beberapa faktor atau dimensi, yaitu garis, arah, bentuk, ukuran, tekstur, nilai dan warna. Agar unsur-unsur desain tersebut dapat disusun dengan menghasilkan efek tertentu, maka diperlukan prinsip-prinsip atau azas-azas desain, sedangkan penyusunan atau pengorganisasian dari unsur-unsur desain tersebut sering disebut juga komposisi (Suryahadi, 1989). Hasil sketsa didokumentasikan untuk kepentingan arsip dan produksi.

\section{Memproduksi Busana}

Memproduksi busana merupakan langkah keempat dalam proses penciptaan busana pada tokoh dalam naskah Piramus dan Tisbi. Dari langkah-langkah di atas ada beberapa tahapan-tahapan sebagai berikut:

\section{a. Melakukan Supervisi Pola dan Gambar Kerja}

Jenis busana yang akan digunakan diidentifikasi sesuai dengan ukuran penggunanya, meliputi seluruh bagian badan yang dibutuhkan secara tepat. Ukuran badan ini digunakan sebagai dasar dalam pembuatan pola busana. Badan pengguna diukur sesuai dengan gambar kerja dan ketentuan pengukuran. Ketentuan pengukuran yang dimaksud, meliputi lingkar leher, lingkar badan, lingkar pinggang, lingkar panggul, tinggi panggul, panjang punggung, lebar bahu, lebar punggung, panjang sisi, lebar muka, panjang muka, tinggi dada, jarak dada, lebar dada, lingkar lubang lengan, dan panjang lengan, panjang rok, panjang celana, tinggi pisak, lingkar paha, lingkar lutut, dan lingkar bawah.

\section{b. Menyeleksi Bahan Busana \\ Bahan busana dipilih sesuai dengan desain busana. Pemilihan bahan busana}


terkait dengan kemampuan pencipta busana dalam memilih bahan yang sesuai dengan rancangan busana, kualitas bahan, karakteristik bahan, dan pemenuhan aspek dramatik dalam pementasan.

\section{c. Melakukan Pembuatan Pola Busana}

Melakukan pembuatan pola busana merupakan proses penciptaan busana pada tokoh dalam naskah Piramus dan Tisbi. Pola merupakan bentuk potongan yang digunakan untuk membuat busana. Pembuatan pola busana terkait kemampuan penata busana dalam membuat pola busana, baik pola konstruksi maupun pola standar. Pola busana dibuat sesuai dengan ukuran tubuh dalam bentuk pola konstruksi. Pola konstruksi adalah pola dasar yang dibuat berdasarkan ukuran badan pemeran dan digambar dengan perhitungan secara matematis sesuai dengan sistem pola konstruksi masing-masing. Pola busana dibuat sesuai dengan desain busana dan ukurannya dalam bentuk pola standar. Pola standar adalah pola yang dibuat berdasarkan daftar ukuran umum atau ukuran yang telah distandarkan, seperti small (S), medium (M), large (L), dan extra large (XL).

\section{d. Melakukan Penjahitan Busana}

Menjahit busana dapat dilakukan sesuai dengan kebutuhan kostum. Bahan dipotong sesuai dengan pola dengan memperhatikan arah serat. Bahan dijahit dengan menerapkan teknik yang sesuai dengan kebutuhan berdasarkan rancangan busana. Menyatukan pola yang sudah dipotong sesuai ukuran merupakan tahapan dalam pembuatan busana. Menyatukan pola busana satu dengan potongan pola lain kemudian dijahit tiap sisinya.

Penyelesaian Akhir Busana

Penyelesaian Akhir Busana atau finishing busana merupakan langkah akhir dalam proses penciptaan busana tokoh dalam naskah Piramus dan Tisbi berikut tahapan-tahapan penyelesaian akhir busana: a. Menerapkan Aksesori dan Perlengkapannya

Aksesori dan perlengkapan busana dikenakan untuk memperkuat karakter tokoh dengan mempertimbangkan karakteristik bahan dan aspek dramatik. Berkaitan dengan berbagai hal yang sudah dikemukakan sebelumnya, maka yang menjadi titik perhatian adalah bagaimana menampilkan sebuah tata busana untuk sebuah pertunjukan.

b. Mengevaluasi Kesesuaian Desain dengan Hasil Akhir

Mengevaluasi kesesuaian desain dengan hasil akhir busana, meliputi pengepasan busana dilakukan sesuai dengan ukuran pengguna. Busana diperbaiki sesuai dengan hasil pengepasan dengan pengguna jika diperlukan. Busana yang telah jadi diterapkan kepada pengguna sesuai dengan desain busana kemudian menerapkan aksesori dan perlengkapannya.

\section{Pembahasan}

Proses penciptaan busana dalam naskah Piramus dan Tisbi telat terlewati dengan banyak tantangan, Tantangan seperti eksplorasi kertas warna putih menjadi berwarna. Sangat sulit karena pada dasarnya konsep busana yang perancang buat ialah menggunakan kertas putih. Tidak mudah dalam mix and match warna perlu tahapan serius dan panjang. Pada saat proses, muncul ide baru misalnya ganti rancangan busana, yang mana perlu mempertimbangkan kenyaman, keamanan busana kertas yang dikenakan agar tidak mudah basah, robek dan dapat menghasilkan efek visual. Namun, ada beberapa hal yang tidak dapat diwujudkan mengingat estimasi waktu yang tidak memungkinkan. Proses penggarapan busana dalam naskah Piramus dan Tisbi 
perlu mempertimbangkan konsep rancangan dengan pembagian tenaga, biaya dan waktu.

Proses penciptaan busana dalam naskah Piramus dan Tisbi memberi pengalaman bagi penata busana. Proses tidak berjalan sesuai ekpektasi ada banyak kendala seperti, pergantian pemain. Tahap pertama ketika pemain ganti secara tidak langsung ukuran busana berubah menyesuaikan pemain yang baru. Tahap kedua, yaitu terbaginya konsentrasi antara penulisan dengan proses pengkaryaan. Tahap ketiga, menunggu barang kertas datang, karena dibeli dari luar kota. Hal ini dikarenakan bahan-bahan tersebut sulit di dapat di kota tinggal. Tahap keempat, tahap evaluasi seminar kedua pada tanggal 21 Desember 2018, banyak harus diperbaiki dari busana dengan rancangan kertas putih. Namun, penata busana berusaha sebaik mungkin dalam menyelesaikan tahapantahapan hingga akhir. Penggunaan kertas sendiri karena kertas berbagai macam jenis, ukuran, warna dan harga. Kelemahan kertas antara lain mudah robek, tidak kedap air dan mudah kusut. Sedangkan kelebihan kertas adalah ringan, ramah lingkungan, mudah diolah dan harganya pun terjangkau. Selama ini tak banyak masyarakat yang memahami cara memanfaatkan kertas dengan baik. Bahan kertas, sebagai media dalam pemanfaatan bahan yang ada, selain itu sebagai strategi untuk mendorong proses imajinatif dan berpikir kreatif.

\section{Simpulan}

Proses penciptaan busana dalam naskah Piramus dan Tisbi dengan material kertas mengalami perubahan-perubahan. Hal tersebut membuang waktu dan tenaga. Karena waktu penggarapan yang begitu singkat. Dalam proses pengkaryaan sebaiknya mempunyai partner dalam pengerjaan busana agar dapat terselesaikan dengan baik. Penggarapan busana tugas akhir ini perlu ketekunan, keamanan dan ketelitian. Semisal pada saat menggunakan lem tembak harus hati-hati karena bahannya yang panas bisa merobek kertas yang digunakan sebagai bahan utama dalam pembuatan busana. Harus teliti juga saat menggunanakan lem tembak terkadang serat-seratnya bisa mengotori busana.

\section{Daftar Pustaka}

Chodiyah \& Mamdy, W. (1982). Disain Busana. Jakarta: Dikmenjur Depdikbud.

Daradjatun, N \& Watimena, S. (2003). Inspirasi Mode Indonesia. Jakarta: Yayasan Buku Bangsa bekerja sama dengan Gramedia Pustaka Utama.

Dewojati, C. (2012). Drama Sejarah, Teori, dan Penerapannya. Yogyakarta: Javakarsa Media.

Harianto. (2002). Terampil Membuat Topeng Kertas. Yogyakarta: Mitra Gama Widya.

Kamil, S. A. (1986). Fashion Design. Jakarta: CV Baru.

Kartika, D. S \& Perwira, N.G. (2004). Pengantar Estetika. Bandung : Rekayasa Sains.

M, Djoddy. (1992). Mengenal Permainan Seni Drama. Surabaya: Arena Ilmu.

Mardjono, H. (1991). Busana Nan Serasi Menampilkan Kharisma Nan

Mempesona. Makalah Seminar Kecantikan Tiara Kusuma Fair.

Nuraini, I. (2011). Tata Rias \& Busana "Wayang Orang Gaya Surakarta". Yogyakarta: Badan Penerbit ISI Yogyakarta.

Prasetya, H.B. (2013). Meneliti Seni Pertunjukan. Yogyakarta: BP ISI Yogyakarta.

Riyanto, A. (2003). Teori Busana. Bandung: Yapemdo.

Riyanto, A. (2009). Modul Dasar Busana Program Studi Pendidikan Tata Busana. Bandung: Yayasan Penerbit Universitas Pendidikan Indonesia. 
Sachari, A. (2002). Estetika, Makna, Simbol dan Daya. Bandung: ITB.

Sahid, Nur. (2004). Semiotika Teater. Yogyakarta: Lembaga Penelitian ISI Yogyakarta.

Stolnitz, J. (1967). dalam Paul Edwards (Ed.). The Encyclopedia of Philosophy. New York: Macmillan.

\section{Lampiran}

\section{Skema Metode Penciptaan}

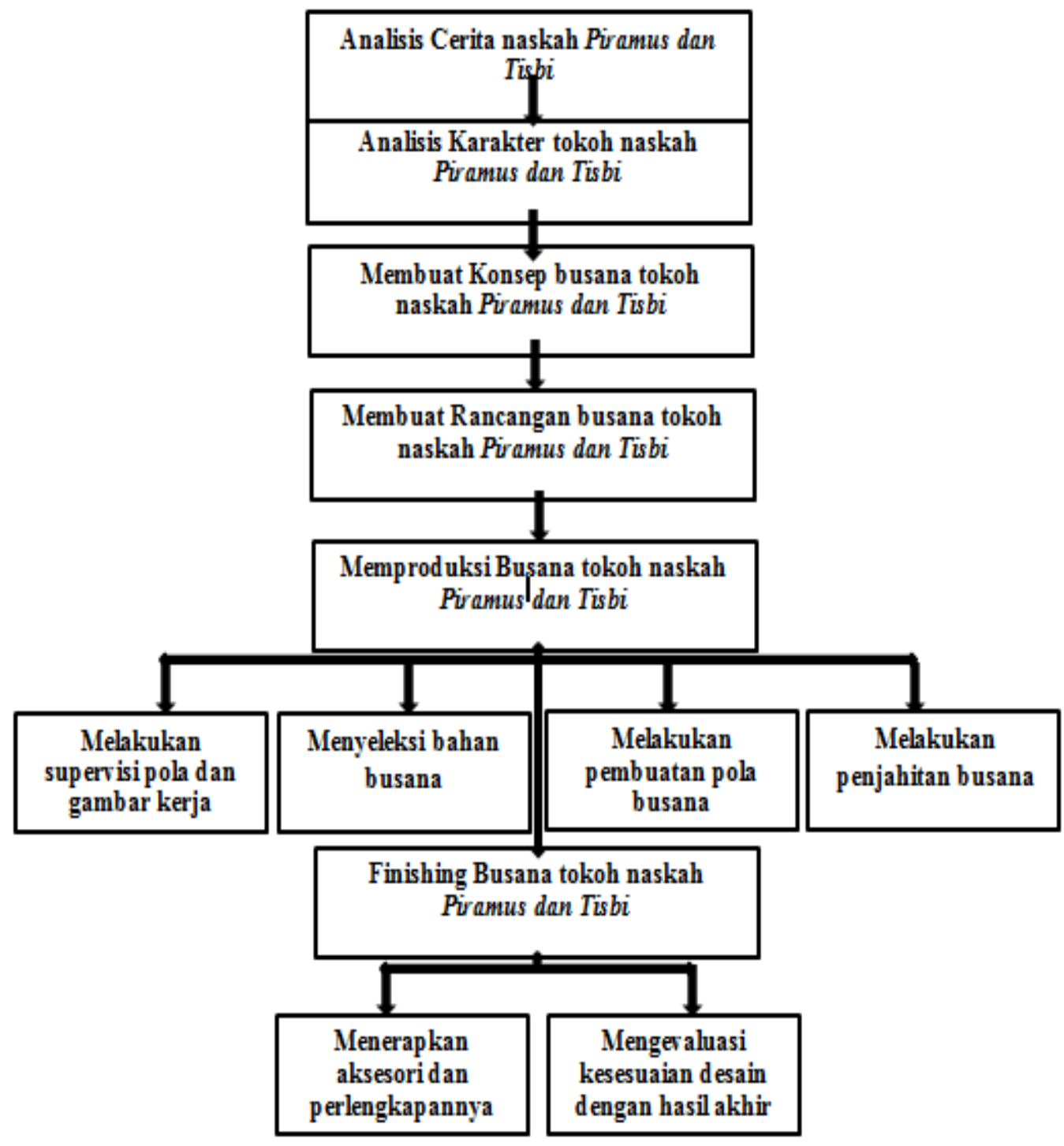

